DOI:

Наталія Арістова, доктор педагогічних наук, доцент, завідувач кафедри англійської філологіі Національного університету біоресурсів і природокористування Украӥни

\title{
АНАЛІТИКО-УЗАГАЛЬНУВАЛЬНЕ ПРЕДСТАВЛЕННЯ ДОСВІДУ ПРОФЕСІЙНОЇ ПІДГОТОВКИ МАЙБУТНІХ ФІЛОЛОГІВ У ПОЛЬЩІ ТА ЛАТВІЇ
}

У статті автор досліджує досвід професійної підготовки майбутніх філологів у Польщі та Латвії. 3'ясовано, щуо у Польщі підготовку майбутніх філологів здійснюють спеціальні заклади вищої освіти, які готують здобувачів ступеня "Молодший бакалавр”, а також заклади вищої освіти університетського та неуніверситетського типів. У Латвії після прийняття Закону “Про навчальні заклади” (1995 р.) встановлено відмінність між вищою академічною освітою та вищою професійною освітою. Проаналізовано зміст освітньопрофесійних програм підготовки майбутніх філологів в Ягеллонському та Латвійському університетах. Визначено, що освітньо-професійна програма підготовки бакалаврів філологічних спеціальностей у Латвійському університеті передбачає чотири роки навчання (8 семестрів), у Ягеллонському - три роки навчання (6 семестрів).

Ключові слова: майбутні філологи; заклад вищої освіти; освітньо-професійна програма; ичилл загальної підготовки; иикл професійної підготовки; професійна підготовка майбутніх філологів; вища освіта; Польща; Латвія.

Jim. 12.

Nataliya Aristova, Doctor of Sciences (Pedagogy), Associate Professor, Head of the English Philology Department,

National University of Life and Environmental Sciences of Ukraine

\section{ANALYTICAL AND GENERALIZING REPRESENTATION OF EXPERIENCE OF FUTURE PHILOLOGISTS' PROFESSIONAL TRAINING IN POLAND AND LATVIA}

In the article the author studies the experience of the future philologists ' professional training in Poland and Latvia. It is found out that in Poland the future philologists ' training is provided by special higher education institutions as well as university-type and non-university higher education institutions. In Latvia the Law "On Higher Education Institutions" adopted in 1995 makes distinction between private and public university-type higher education institutions which offer academic and professional programs and private and public non-university-type ones which offer only professional programs. In Latvia public universities train future specialists in Latvian which is the only State language of Latvia. Latvian university-type and non-university-type higher education institutions provide various first-cycle, second-cycle and/or long-cycle programs for training the future philologists. The content of academic and professional curricula in Jagiellonian and Latvian universities is analyzed. It is determined that the future philologists' training at Latvian university lasts four years (from six to eight semesters) and at Yagiellonian university - three years (six semesters). The main peculiarity of training the future philologists at Polish and Latvian universities is that they study only professional disciplines which focus on the core areas of English Philology and aim at formation and development of key and subject-matter competencies as well as different general and technical skills and professional values necessary for successful career building. General skills necessary for future philologists are critical thinking, creativity, teamwork and multitasking. After obtaining a degree, the future philologists are ready for various academic and professional careers in the public and private sector of labor market.

Keywords: the future philologists; higher educational institution; academic and professional curriculum; the future philologists' professional training; higher education; Poland; Latvia.

П остановка потреби. Підвищення вимог до рівня професійної підготовки сучасних фахівців філологічної галузі зумовлює необхідність упровадження інноваційних моделей, технологій, форм, методів, прийомів і засобів навчання, спрямованих на активацію розвиткузагальних і предметних компетентностей майбутнього філолога. Одним із шляхів застосування інновацій в освітньому процесі й удосконалення змісту професійної підготовки майбутніх філологів $є$ дослідження міжнародного досвіду. Таким досвідом може стати вивчення питань, пов'язаних із здійсненням освітньої діяльності закладів вищої освіти у Польщі та Латвії в умовах автономії, наданням більшої академічної свободи здобувачам вищої освіти та розвитком академічної мобільності всіх суб'єктів навчання.

Аналіз досліджень. Певні теоретичні аспекти підготовки майбутніх філологів у зарубіжних закладах вищої освіти розглядаються у наукових 


\section{АНАЛТТКО-УЗАГАЛЬНУВАЛЬНЕ ПРЕДСТАВЛЕННЯ ДОСВІДУ ПРОФЕСІЙНОЇ ПЦДГОТОВКИ МАЙБУТНІХ ФІЛОЛОГІВ У ПОЛЬЩІ ТАЛАТВІЇ}

працях Т. Григор'євої [2], I. Задорожної [3], I. Кононенко [4], I. Пасинкової [5], І. Суріної [6]. Проте, грунтовні наукові напрацювання з проблем професійної підготовки філологів в освітньому досвіді Польщі і Латвії відсутні.

Мета статті - проаналізувати та узагальнити досвід закладів вищої освіти Польщі та Латвії задля його використання упрофесійній підготовці майбутніх філологів в Україні.

Виклад основного матеріалу. Теоретичний аналіз наукової педагогічної літератури, дає змогу стверджувати, що для України неоціненим досвідом реформування і модернізації системи вищої освіти можуть стати суттєві позитивні перетворення, які вже відбулися у системах вищої освіти Республіки Польщі та Латвії. Саме у цих країнах уже запроваджено нові моделі вищої освіти, які передбачають більшу автономність університетів у розробленні та впровадженні освітньо-професійних програм, а також більшу свободу у створенні авторських курсів і спеціальностей. Так, наприклад, 31 жовтня 2012 p. у Республіці Польща скасовано державні стандарти вищої освіти і не регламентується перелік спеціальностей. Завдяки цьому, заклади вищої освіти мають змогу самостійно розробляти освітньо-професійні програми, враховуючи загально-польські рамки кваліфікацій та “ефекти навчання”, під якими розуміють знання, уміння, навички та соціальні компетентності, які майбутні фахівці здобувають у процесі професійної підготовки [6;8; 12]. Заклади вищої освіти у Польщі здійснюють підготовку майбутніх філологів за трьома типами освітньо-професійних програм - програми, які пропонують спеціальні заклади вищої освіти; програми для здобуття ступеня "Бакалавр" та "Магістр"; програми для здобуття ступеня“ Доктор філософіі” $[12,61]$. Підготовка фахівців з іноземної філології за програмами, які пропонують спеціальні заклади вищої освіти, здійснюється у педагогічних коледжах $з$ підготовки вчителів іноземних мов (nauczycielskie kolegium języków obcych). Цi коледжі готують вчителів іноземних мов для всіх рівнів шкільної освіти - від початкової до старшої школи, а також для інших закладів освіти, які забезпечують підготовку здобувачів освітнього ступеня “Молодший бакалавр” [8; 11; 12]. Підготовка бакалаврів та магістрів зі спеціальності “Англійська філологія” здійснюється у вищих закладах освіти університетського або неуніверситетського типу, діяльність яких регламентується "Законом про вищу освіту” від 27 липня 2005 року. До закладів вищої освіти університетського типу відносять такі, в яких принаймні один факультет готує здобувачів ступенів “Бакалавр”, “Магістр” і “Доктор філософії; неуніверситетського типу - заклади вищої освіти, в яких не готують здобувачів освітнього ступеня “Доктор філософії” [8; 11; 12].

У свою чергу, у системі вищої освіти Латвії більш як 30 вищих навчальних закладів, з яких близько половини є державними, а інші приватними. Після прийняття Закону "Про навчальні заклади" ("Law on Education Establishments" у 1995 р., яким встановлено відмінність між вищою академічною освітою та вищою професійною освітою, систему вищої освіти в Латвії можна вважати двокомпонентною. Це означає, що існує чітке розмежування між академічними закладами вищої освіти (університет, академія, вища школа) і професійними (коледж). Так, згідно із законодавством Латвії тільки університети можуть здійснювати підготовку здобувачів вищої освіти за академічними програмами, які передбачають формування i розвиток теоретичних знань та практичних умінь і навичок для здобуття ступеня “Бакалавр”, та професійними програмами, які передбачають формування і розвиток практичних знань, умінь $і$ навичок у певній сфері діяльності. Коледжі здійснюють підготовку фахівців тільки за професійними програмами [10]. Варто зазначити, що латвійські державні заклади вищої освіти відповідно до програм підготовки здійснюють освітній процес тільки державною мовою, у той час як приватні заклади вищої освіти можуть забезпечувати навчання ще й мовами національних меншин. Перелік навчальних дисциплін, викладання яких здійснюється виключно державною мовою, визначає саме міністерство освіти і науки Латвії [10].

У закладах вищої освіти Латвії програми підготовки здобувачів ступня бакалавр за різними спеціальностями розраховані на 3 або 4 роки навчання і передбачають опанування нормативних і вибіркових навчальних дисциплін в обсязі 120 160 кредитів СКТС (за національною системою), 3 яких 10 кредитів СКТС відводиться на написання дипломної роботи (1 ЄКТС за національною системою у Латвії дорівнює 1,5 ЄКТС за європейською системою, а 1 кредит дорівнює 40 академічним годинам). До головної особливості освітньо-професійних програм підготовки майбутніх фахівців в університетах Латвії можна віднести те, що на нормативні навчальні дисципліни відводиться 50 \% від загального обсягу годин, на вибіркові навчальні дисципліни (за вибором вищого навчального закладу) - 20 \% 


\section{АНАЛТТИКО-УЗАГАЛЬНУВАЛЬНЕ ПРЕДСТАВЛЕННЯ ДОСВІДУ ПРОФЕСИЙНОЇ ПДГОТОВКИ МАЙБУТНІХ ФІЛОЛОГІВ У ПОЛЬЩІТАЛАТВІЇ}

і на вибіркові навчальні дисципліни (за вибором студента) - 30 \%. Протягом семестру здобувачі вищої освіти вивчають не більш ніж 6 нормативних навчальних дисциплін [10].

Розглянемо зміст програм підготовки (навчальних планів) здобувачів ступеня "Бакалавр" зі спеціальності “Англійська філологія” у Ягеллонському і Латвійському університетах. Так, одним із польських університетів до досвіду якого варто звернутися $є$ Ягеллонський університет, заснований у 1364 p. Казимиром Великим. На сьогодні Ягеллонський університет має 15 факультетів, де навчається близько 50 тисяч студентів. Це факультет права та адміністрування, лікувальний факультет, фармацевтичний факультет, факультет наук про здоров'я, філософський факультет, історичний факультет, філологічний факультет, факультет полоністики, факультет фізики, астрономії та прикладної інформатики, факультет математики та інформатики, хімічний факультет, факультет біології і наук про Землю, факультет менеджменту та соціальної комунікації, факультет міжнародних і політичних досліджень, факультет біохімії, біофізики та біотехнологій. Усі освітньо-професійні програми відповідають вимогам Болонського процесу, в університеті діє система European Credit Transfer System (ECTS), що забезпечує зв’язок навчання в Ягеллонському університеті з навчанням в університетах інших європейських країн і сприяє академічній мобільності студентів і викладачів завдяки партнерським угодам 3 багатьма зарубіжними закладами вищої освіти $[8 ; 9 ; 11 ; 12]$.

До складу філологічного факультету Ягеллонського університету входять вісім інститутів, одним 3 яких є Інститут англійської філології. Студенти мають можливість здобувати філологічну освіту за такими ступенями як “Бакалавр", "Магістр” та “Доктор філологічних наук”. Навчання триває 6 семестрів. Для завершення навчання й отримання диплома про вишу освіту випускникові Інституту англійської філології Ягеллонського університету необхідно набрати 180 ECTS. Як і у всіх університетах Польщі структуру освітньо-професійної програми становлять дисципліни циклу професійної підготовки, які сприяють набуттю ключових і предметних компетентностей, необхідних на сучасному ринку праці, а також формуванню та розвитку критичного мислення, креативності, уміння працювати в команді і виконувати декілька завдань одночасно тощо [8; 9].

У свою чергу, у Латвії одним із провідних закладів вищої освіти є Латвійський університет, який було засновано 28 вересня 1919 року на базі
Ризького політехнічного університету. У 2010 році після злиття факультету філології та гуманітарних наук і факультету сучасних мов було створено гуманітарний факультет Латвійського університету, на якому навчається понад 2000 студентів. Головною метою діяльності гуманітарного факультету є формування та розвиток загальних і предметних компетентностей здобувачів вищої освіти у таких сферах, як лінгвістика, літературознавство, фольклористика, антропологія, мистецтво (теорія і історія театру) тощо [10]. Освітньо-професійна програма підготовки здобувачів ступеня “Бакалавр” зі спеціальності “Англійська філологія” на гуманітарному факультеті Латвійського факультету розрахована на 4 роки навчання (денна форма) або 5 років (заочна форма) i передбачає оволодіння нормативними і вибірковими навчальними дисциплінами циклу професійної підготовки в обсязі 160 кредитів за національною шкалою (240 кредитів СКТС). Нормативними навчальними дисциплінами $є$ "Вступ до навчання та дослідної роботи”, “Вступ до мовознавства”, “Фонетика і фонологія англійської мови”, “Граматика англійської мови”, “Практичний курс основної іноземної мови (англійська мова)”, “Комплексний аналіз тексту”, “Вступ до літературознавства”, “Основи латвійської наукової мови і термінології', “Латинська мова”, “Історія англійської мови”, “Основи перекладознавства”, “Методи дослідження в літературі”, “Комунікативна психологія”. Дисципліни за вибором університету включають “Другу іноземну мову”, “Британська культура/ Культура США/ Кельтська література і культура/ Канадська культура”, “Література Середнього віку та Ренесансу”, “Вступ до прикладної лінгвістики”, “Англійська література Класицизму і Просвітництва”, “Лексикологія і стилістика англійської мови”, “Романтизм в англійській літературі / Романтизм в американській літературі”, “Методи дослідження в лінгвістиці”, “Теоретична граматика і фонетика англійської мови”, “Англійська література періоду Реалізму 19 ст.”, “Мова, Культура, Переклад / Виробнича практика / Креативне письмо / Американська література періоду Реалізму", “Переклад (семінарські заняття)”, “Вступ до діалектів англійської мови”, “Література Модернізму і Постмодернізму” [7].

Варто зазначити, що у процесі професійної підготовки здобувачі освітнього ступеня "Бакалавр" зі спеціальності “Англійська філологія” на гуманітарному факультеті Латвійського університету мають здобути певні теоретичні знання і розвивати практичні вміння 


\section{АНАЛТТИКО-УЗАГАЛЬНУВАЛЬНЕПРЕДСТАВЛЕННЯ ДОСВІДУ ПРОФЕСЙ̆НОЇ ПІДГОТОВКИ МАЙБУТНІХ ФІЛОЛОГІВ У ПОЛЬЩІ ТАЛАТВІЇ}

та навички. Здобуття теоретичних знань, які необхідні для продукування нових ідей, розв'язання комплексних проблем у галузі філології, передбачає адекватне сприйняття текстової інформації іноземною мовою; адекватне сприйняття інформації на слух; вільне й грамотне спілкування іноземною мовою в письмовій формі 3 дотриманням лексичних, граматичних та стилістичних норм; вільне й грамотне спілкування іноземною мовою в усній формі з дотриманням фонетичних, лексичних, граматичних та стилістичних норм; урахування комунікативнопрагматичних особливостей мовленнєвої ситуації та iї соціокультурного контексту під час здійснення процесу міжкультурної комунікації; використання досягнень сучасної філологічної науки для дослідження актуальних питань лінгвістики; аналіз мовних явищ в їх взаємозв'язку та взаємозалежності $[1 ; 7 ; 10]$.

Розвиток практичних знань, умінь і навичок 3 предметної галузі передбачає їх використання в організації навчально-виховного процесу у загальноосвітніх середніх школах; здійсненні добору мовного матеріалу, орієнтованого на певну аудиторію з урахуванням вікових та психологічних особливостей суб' єктів навчання; забезпеченні впливу на аудиторію; пошуку, аналізі й опрацюванні необхідної інформації та ії адекватній презентації; оформленні результатів своєїпрофесійної діяльності відповідно до чинних стандартів $[1 ; 7 ; 10]$.

Бакалавр-філолог може працювати в освітній, науковій, економічній галузях, у різноманітних фондах, спілках, фундаціях, центрах гуманітарного спрямування тощо. Крім того, бакалавр з іноземної філології підготовлений для подальшого здобуття повної вищої освіти та освітнього ступеня "Магістр" зі спеціальності “Англійська філологія”, а його предметна компетентність передбачає розуміння загальної структури філологічної науки; розуміння лінгвістики як особливої науки, що вивчає структуру і функціонування мови; володіння знаннями з усіх галузей мовознавства; володіння основними поняттями, концепціями і фактами сучасної літературознавчої науки; здатність оперативно засвоювати нові теорії, концепції, методики дослідження як у галузі філології, так і на межі різних гуманітарних наук; уміння правильно застосовувати теорію компаративістики до літературного матеріалу. Ці фахівці здатні виконувати письмовий переклад різних за змістом та жанрово-стилістичними характеристиками текстів 3 англійської мови латвійською та 3 латвійської мови англійською; усний переклад 3 англійської мови латвійською та з латвійської мови англійською; редагувати переклади, виконані англійською та латвійською мовами; різні види робіт, які пов'язані з іншомовною комунікацією; викладати англійську мову у середніх закладах освіти $[1 ; 7 ; 10]$.

Отже, за результатами аналізу навчальних планів підготовки здобувачів ступеня "Бакалавр" зі спеціальності “Англійська філологія” у Ягеллонському університеті можна стверджувати, що у процесі підготовки майбугніх філологів акцент робиться на здобуття теоретичних знань і розвиток практичних умінь і навичок, необхідних для успішної реалізації подальшої професійної діяльності. Підготовка до здобуття освітнього ступеня “Бакалавр” розрахована на 6 семестрів (3 роки навчання) [8; 9]. На відміну від польських університетів, підготовка до здобуття освітнього ступеня “Бакалавр” у Латвійському університеті розрахована на 8 семестрів (4 роки навчання) i передбачає опанування нормативних і вибіркових навчальних дисциплін в обсязі 160 кредитів ECTS за національною системою, що дорівнює 180 кредитів ECTS за загальноєвропейською системою $[7 ; 10]$.

Істотна відмінність між програмами підготовки здобувачів ступеня "Бакалавр” зі спеціальності “Англійська філологія” полягає в тому, що до освітньо-професійних програм польських і латвійських університетів входять тільки навчальні дисципліни циклу професійної підготовки. Курс навчання триває 6 семестрів у вищих навчальних закладах Республіки Польща і 8 семестрів у Латвії. Для здобуття освітнього ступеня “Бакалавр” у Республіці Польща і Латвії необхідно набрати 180 ECTS, у той час як випускникам українських вищих закладів освіти - 240 ECTS $[7 ; 8 ; 9 ; 10 ; 11 ; 12]$.

Крім того, аналіз навчальних планів українських і зарубіжних університетів дає нам підстави стверджувати, що професійна підготовка майбутніх фахівців з іноземної філології у вищих закладах освіти Республіки Польща і Латвії спрямована на формування активної, автономної, ініціативної і відповідальної особистості майбутніх філологів, на відміну від української системи вищої освіти, в якій акцентується увага здебільшого на теоретичному засвоєнні певної системи знань, умінь і навичок. Освітньо-професійні програми університетів Республіки Польща і Латвії сприяють розвитку навичок самостійного навчання, готовності до здійснення самостійного вибору, відповідальності і самостійного прийняття рішень, роботи в команді. Бакалаври з іноземної філології добре підготовлені до подальшого як наукового, так і практичного навчання, готові 


\section{АНАЛТТИКО-УЗАГАЛЬНУВАЛЬНЕ ПРЕДСТАВЛЕННЯ ДОСВІДУ ПРОФЕСІЙНОЇ ПІДГОТОВКИ МАЙБУТНІХ ФІЛОЛОГІВ У ПОЛЬЩІ ТАЛАТВЇ̈}

виконувати роботу, яка потребує високої кваліфікації, оскільки не тільки усвідомлюють значимість своїх знань, умінь і навичок, а й можугь проектувати шлях особистого розвитку [1].

\section{ЛІТЕРАТУРА}

1. Арістова Н. О. Теоретичні і методичні засади формування професійної суб'єктності майбутніх філологів [Текст]:дис. ... д-ра пед. наук: 13.00.04 / Наталія Олександрівна Арістова; Національний авіаційний університет. - Київ, 2017. -572 с.

2. Григор'єва Т. Ю. Підготовка вчителів-філологів до навчання дорослих у системі неперервної освіти Великої Британії: автореф. дис. на здобуття наук. ступеня канд. пед. наук: спец. 13.00.04 “Теорія і методика професійної освіти” / Т. Ю. Григор'єва. - Житомир, 2010. $-20 \mathrm{c}$

3. Задорожна I. П. Особливості методичної підготовки вчителів англійської мови уВеликій Британії: автореф. дис. на здобуття наук. ступеня канд. пед. наук: спец. 13.00.04 "Теорія і методика професійної освіти"/ І. П. Задорожна. - Тернопіль, 2002. - 20 c.

4. Кононенко I. А. Професійне становлення майбутніх учителів філологічних спеціальностей у системі вищої освіти Франції [Текст]: дис. ... к. пед. наук: 13.00.04 / Інна Анатоліївна Кононенко. - ПереяславХмельницький, 2017. -319 с.

5. Пасинкова I. В. Система підготовки бакалаврів гуманітарних наук з іноземної мови в університетах США: автореф. дис. на здобугтя наук. ступеня канд. пед. наук: спец. 13.00.04 “Теорія і методика професійної освіти” / І. В. Пасинкова. - Київ, 2005. - 20 с.

6. Сурина И. А. Система высшего образования Польши перед вызовами современности / И. А. Сурина // Гуманітарний вісник ДВНЗ "ПереяславХмельницький державний педагогічний університет імені Григорія Сковороди" : додаток 1 до Вип. 5, Т. I (52): тематич. вип. "Вища освіта України у контексті інтеграції до європейського освітнього простору”. Київ:Гнозис, 2014. - С. 366-377.

7. Bachelor's degree programme ENGLISH PHILOLOGY / Latvijas Universitate [Електронна версія]. - Режим доступу: http://www.lu.lv/fileadmin/user_upload/ $1 u_{-}$portal/eng/international_students/ English_philology_BSP_courses2013.pdf--Назва з екрану.

8. Higher education [Електронний ресурс] / Ministry of Science and Higher education (Republic of Poland) Режим доступу: http://www.nauka.gov.pl/en/highereducation// - Назва з екрану.

9. Institute of English Studies of the Jagellonian University [Електронний ресурс]. - Режим доступу: http://www.ifa.filg.uj.edu.pl/en GB/rok-i-1 - Назва 3 екрану.

10. Latvia Higher Education System [Електронний pecypc]. - Режим доступу: http://www.euroeducation.net/ prof/latviaco.htm - Назва з екрану.

11. Law on Higher Education [Електронний ресурс]Режим доступу: https://www.nauka.gov.pl/g2/oryginal/ 2013 05/ff45b4be7d6682f90d4755ddc6373a70.pdf- Назва 3 екрану.
12. The system of Education in Poland - Warsawa: Foundation for the Development of the Education System, 2012. $-132 \mathrm{p}$

\section{REFERENCES}

1. Aristova, N. O. (2017). Teoretychni i metoduchni zasady formuvannia profesiinoi subiektnosti maibutnikh filolohiv [Theoretical and methodical foundations of forming future philologists' professional agency]. Kyiv, 572 p. [in Ukrainian]

2. Hryhorieva, T. Yu. (2010). Pidhotovka vchytelivfilolohiv do navchannia doroslykh u systemi neperervnoi osvity Velykoi Brytanii i osvity [Training of teachersphilologists to teaching adults in the system of continuing education of Great Britain]. Extended abstract of candidate's thesis. Zhytomyr, 20 p. [in Ukrainian].

3. Zadorozhna, I. P. (2002). Osoblyvosti metodychnoi pidhotovky vchyteliv anhliiskoi movy u Velykii Brytanii [Peculiarities of methodical training of English language teachers in Great Britain]. Extended abstract of candidate's thesis. Ternopil, 20 p. [in Ukrainian].

4. Kononenko, I. A. (2017). Profesiine stanovlennia maibutnikh uchyteliv filolohichnykh spetsialnostei u systemi vyshchoi osvity Frantsii [Professional development of future teachers of philological specialties in the system of higher education of France]. Candidate's thesis. Pereiaslav-Khmelnytskyi, 319 p. [in Ukrainian].

5. Pasynkova, I. V. (2005). Systema pidhotovky bakalavriv humanitarnykh nauk z inozemnoi movy v universytetakh SshA [The system of training of bachelors of arts in foreign languages at universities of the USA]. Extended abstract of candidate's thesis. Kyiv, 20 p. [in Ukrainian].

6. Suryna, Y. A. (2014). Systema vysshego obrazovanyia Polshy pered vyzovamy sovremennosty [The system of higher education of Poland in the face of challenges of modernity]. Humanitarian Journal DVNZ "PereiaslavKhmelnytskyi national pedagogical university named after Hryhoriy Skovoroda". Kyiv, pp. 366-377. [in Russian].

7. Bachelor's degree programme English philology/ Latvijas Universitate. Retrieved 10/11/2016 from http:// www.lu.lv/fileadmin/user_upload/lu_portal/eng/ international_students/English_philology_BSP_courses 2013.pdf[in English].

8. Higher education. Ministry of Science and Higher education (Republic of Poland). Retrieved 16/07/2018, from http://www.nauka.gov.pl/en/higher-education/[in English].

9. Institute of English Studies of the Jagellonian University. Retrieved 16/07/2018, from http:// www.ifa.filg.uj.edu.pl/en_GB/rok-i-1[in English].

10. Latvia Higher Education System. Retrieved 16/07/ 2018, from http://www.euroeducation.net/prof/latviaco.htm [in English].

11. Law on Higher Education (2005). Retrieved 16/07/ 2018, from https://www.nauka.gov.pl/g2/oryginal/2013 05/ ff45b4be7d6682f90d4755ddc6373a70.pdf[in English].

12. The system of Education in Poland (2012). Warsawa: Foundation for the Development of the Education System, 132 p. [in English].

Стаття надійшла до редакції 30.07.2018 